\title{
A critical review on: Significance of floral homeotic APETALA2 gene in plant system
}

\author{
Pooja Sharma*, Raj Singh, Nirmala Sehrawat \\ Department of Biotechnology, MMEC, MMDU, Mullana, Ambala 133207, India.
}

\begin{tabular}{l}
\hline ARTICLE INFO \\
\hline Received on: 09/05/2019 \\
Accepted on: 25/11/2019 \\
Available online: 03/01/2020 \\
\\
\hline Key words: \\
APETALA2, transcription \\
factor, miRNA172, floral \\
development, RNA-induced \\
silencing complex, nitrogen \\
use efficiency.
\end{tabular}

\begin{abstract}
Flower development is a complex procedure regulated by combinatorial factors, such as transcription factors, peptides, hormones, and small RNAs. One of the important gene determining the floral structure and floral meristem is APETALA2 (AP2) which belongs to a large family of transcription factors. AP2 contributes stochastically in signaling pathway in flower development and in various bioactive components synthesis. The presence of $G b A P 2$ transcripts in live fossil Ginkgo biloba leaves and female strobili tissue showed that GbAP2 might be involved directly in leaf and female strobili development, whereas it may possible that GbAP2 indirectly involved in synthesis of bioactive compounds such as flavonoids, terpenoids, ginkgolides, and organic acids. Gingko or Ginkgo biloba is among the most popular plant used in United States. Bioactive compounds isolated from the ginkgo plant are thought to exhibit as antioxidant and antiplatelet activity. Due to the pleotropic nature of $A P 2$, it is involved in various tissues such as regulating in floral pattern, stem cell maintenance, floral organ identity, floral meristem, leaves, development of stems, and seed development. $A P 2$ also regulate number of downstream genes but its own expression is negatively regulated at translational or post-translational levels by miRNA172 which is a small RNA ( $22 \mathrm{bp}$ ) and binds to complementary region of $A P 2$ transcript. Mutation in $A P 2$ showed increases in seed size and seed mass, this property of $A P 2$ could be used in medicinal plant to enhance the valuable product. Since $A P 2$ is engaged in various pathways it is essential to compile the functioning in the form of presented manuscript, which discusses the structure and functioning of $A P 2$. We likewise explain how $A P 2$ involved in various expressions and its regulatory mechanism, especially in the plant.
\end{abstract}

\section{INTRODUCTION}

According to the ABCDE model, APETALA2 (AP2) gene belongs to Class A gene category primary in Arabidopsis, which is responsible for sepal and petal development. It is one of the significant genes responsible to determine the identity of four major floral organs. Any type of alteration in $A P 2$ gene sequence could cause severe developmental defects, especially homeotic floral organ distortion where petals are replaced by carpels or carpelloids and petals to stamens. In the case of weak $A P 2$ mutant plant, the leaves were replaced by sepals and petals by antheroid, whereas in strong $A P 2$ mutant plant, carpelloidlike structures were formed in place of sepals, petals are demised,

\section{*Corresponding Author}

Pooja Sharma, Department of Biotechnology, MMEC, MMDU, Mullana, Ambala 133207, India.E-mail: pooja0029@gmail.com and the stamen number is reduced. In recent years, scientists pay more focus on RNA interference (RNAi) to characterize the gene function in model and cultivated plants. RNAi is a technique of gene editing which is based on post-transcriptional gene silencing in eukaryotes to modify the phenotypes. Various small interfering RNAs (siRNAs) and micro RNAs (miRNAs) molecules are characterized which involved in gene regulation in plants system at transcriptional as well as translational levels. A $m i R 172,22$ bp in length showing similarity with the transcript of a floral homeotic gene $A P 2$ and regulates its expression pleiotropically. The accumulation of enhanced miR172 showing the same floral defects as shown in loss-offunction AP2 mutants. In 2005, two scientists Axtell and Bartel were reported that $m i R 172$ regulates in flowering plants, ferns, and gymnosperms except lycopods and moss (Axtell and Bartel, 2005). Recently in monocotyledons, such as maize, barley, and rice have shown the functioning of $m i R 172$ in differential stage 
transition in flower development (Lauter et al., 2005; Nair et al., 2010; Zhu and Helliwell, 2011).

During flower development, a cassette of regulatory genes has been revealed, which works collectively to regulate the floral meristem and floral organogenesis. The identification of floral organ is regulating under the influence of consistent homeotic genes. Homeotic genes are the regulatory genes that direct the position and development of particular body segments or structures. AP2 is one of the important homeotic gene, which governs the determination of floral meristem and floral development. To differentiate the flowering genes, the $\mathrm{ABC}$ model was designed which further modified as the ABCDEmodel offlower development(Colombo etal., 1995; Haughn and Somerville, 1988; Pelaz et al., 2000). Various combinatorial interaction of homeotic genes involved in flower development. Floral genes based on the ABCDE model are categorized in five different classes, such as A, B, C, D, and E (Bowman et al., 1991). Class A genes ( $A P 1, S Q U A$, and $A P 2)$ control sepal development in whorl 1. Class A genes overlap with Class $\mathrm{B}$ genes ( $P I$ and $A P 3)$ to promote petal formation in whorl 2. Class B and Class $\mathrm{C}(A G)$ genes involved in stamen formation in whorl 3, while Class $\mathrm{C}$ genes alone promote gynoecium development in whorl 4 (Fig. 1) To sustain the floral structure, Class $\mathrm{A}(A P 2)$ and Class $\mathrm{C}(A G)$ genes act mutually but in antagonistic fashion. Thus, $A P 2$ and $A G$ gene transcription spatially restricted by the first two whorls and last two whorls, respectively.

$A P 2$ is one of the significant genes known from the decades for governing floral meristematic and floral organ tissue determination (Bowman et al., 1989; 1993; Huala and Sussex 1992; Irish and Sussex 1990; Komaki et al., 1988; Kunst et al., 1989;

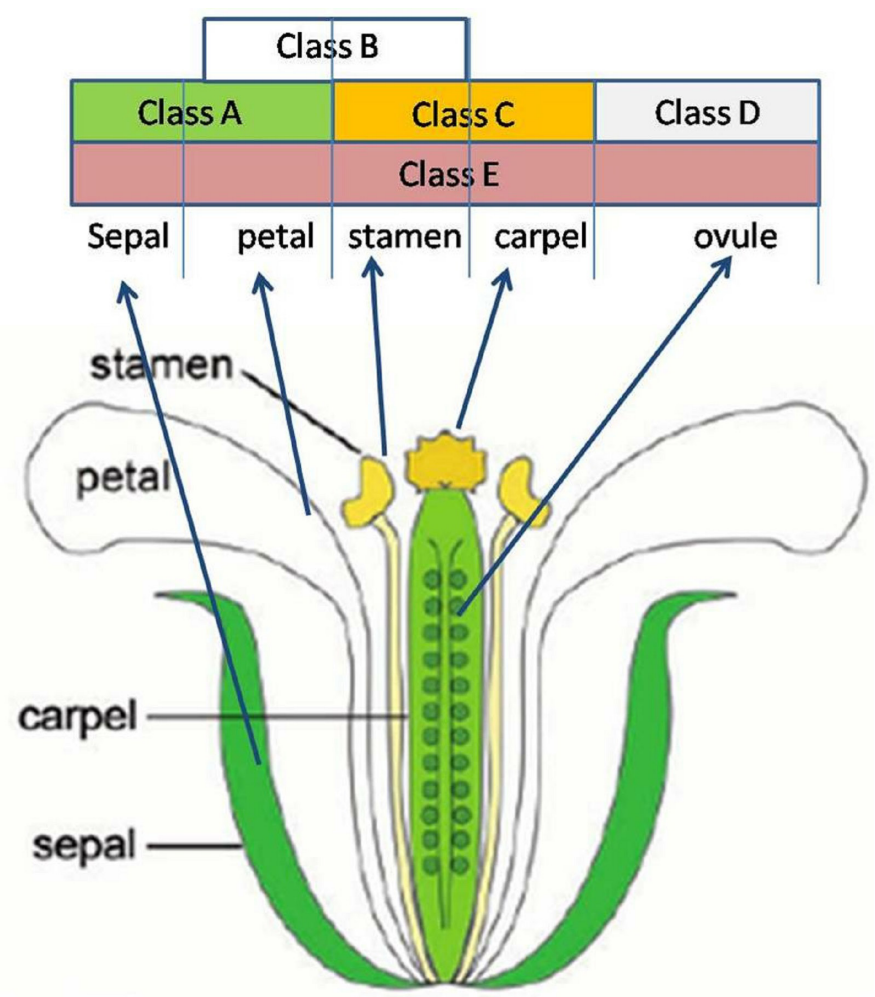

Figure 1. Representation of class A, B, C, D, and E genes with their respective tissue in model flower (modified from Krizek and Fletcher, 2005).
Schultz and Haughn 1993; Shannon and Meekswagner 1993). The presence of $A P 2$ transcripts in floral (sepal, petal, anther, ovule, and silique) as well as in vegetative tissues (root, leaf, shoot, and stem) showed the importance of $A P 2$ gene in reproductive and vegetative tissues (Sharma et al., 2017). Since high level of $A P 2$ protein was observed in vegetative tissue, but still there is no report on any defects in stem or leaf development. Consequently, lossof-function completely distorts the structure of flower but leaf and root structure seems healthy (Bowman et al., 1989). Besides this, it is hypothesized the $A P 2$ function in stem and leaf may be due to the genetically redundancy in Arabidopsis (Okamuro 1997).

\section{CLASSIFICATION AND STRUCTURAL ORGANIZATION OF $A P 2$ GENE}

Floral homeotic AP2 gene belongs to APETALA2/ Ethylene Responsive Factor super family. The genes belong to this family are involved in primary and secondary metabolism regulation, growth, and development. It also involved in abiotic responses. $A P 2$ itself is a transcription factor which represents 147, 157, 201, and 148 targets in Arabidopsis, rice, wheat, and soya bean, respectively (Nakano et al., 2006; Sahu et al., 2016; Yant et al., 2010; Zhang et al., 2008). Respective targets have been divided into three different classes based on the number of $A P 2$ domains. Class I encodes a functional protein having two $A P 2$ domains, for example AP2 (Jofuku et al., 1994), AINTEGUMENTA (ANT) (Elliott et al., 1996; Klucher et al., 1996), Glossy15 (GL15) (Moose and Sisco 1996), SlAP2a (Karlova et al., 2011), SHAT1, and BniAP2. Class II encodes a functional protein having single $A P 2$ domain, for example Ethylene-Responsive-element-bindingFactor (ERFs) (Ohme-Takagi and Shinshi 1995), It is a mutation caused by transposon element (TINY) (Wilson et al., 1996), AtEBP (Buttner and Singh 1997), and ABI4 (Finkelstein et al., 1998) and a Class III includes Related to ABI3/VP (RAV) (Kagaya et al., 1999 ) encodes a protein having one $A P 2$ associated with B3 DNAbinding domain (Giraudat et al., 1992). Some additional sequence conserved in plants genome belonging to the AP2/ EthyleneResponsive-element-binding-Factor (ERF) family known as soloist (Licausi et al., 2010; Nakano et al., 2006; Zhuang et al., 2008).

Since 1994, it is known that transcription start site (TSS) of $A P 2$ is positioned at 263 bp upstream to the start codon (Jofuku et al., 1994). Recently, it is confirmed that AP2 having multi-TSS site responsible for gene expression (Sharma et al., 2017). $A P 2$ is regulated by nearly $7.5 \mathrm{~Kb}$ flanking region located at fifth chromosome in model plant (Arabidopsis) with gene id: $A T 4 G 36920$. The structure of AP2 gene comprised 10 exons and 9 introns with a transcript ranges from 1,300 to 1,500 bp (Fig. 2). $A P 2$ gene comprised two $A P 2$ domains, which are essential for $A P 2$ function. Each $A P 2$ domain is comprised 68 amino acids, which is evolutionary conserved in plants as $A P 2$-like proteins. There were two conserved sequence box within each $A P 2$ domain.

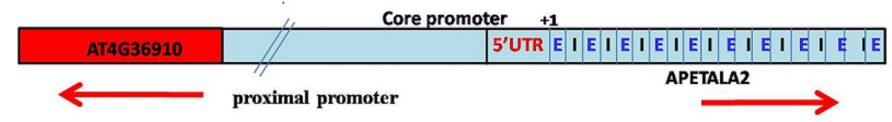

Figure 2. Structure of $A P 2$ gene with 10 exon-9 intron boundaries with intergenic region and adjacent gene (AT4G36910) in reverse orientation. 
The first motif comprised 19-22 basic amino acids and a conserved Tyrosine-Arginine-Glycine motif (Basic amino acids) (YRG) amino acids motif whereas the second motif comprised 42-43 amino acids with 18 amino acids as a core region that forms an amphipathic $\alpha$-helix, which is essential for $A P 2$ functioning (Allen et al., 1998; Jofuku et al., 1994). The AP2-like proteins are also characterized by the presence of linker region that is comprised 25-26 highly conserved amino acids and lies between the two AP2 domains (Allen et al., 1998; Jofuku et al., 1994).

It was considered that $A P 2$ domain presents within plant system only (Riechmann and Myerowitz, 1998) but computerassisted study search that Histidine and Asparagine rich AsparagineHistidines domain $(H N H)-A P 2$ class of homing endonucleases were also present in Cyanobacterium (Trichodesmium erythraeum) and virus genome (Enterobacteria phage and Bacteriophage Felix) suggesting the horizontal transfer of Asparagine- Histidines domain $(H N H)-A P 2$ from bacteria to plants. Furthermore, intronless $A P 2 /$ Ethylene-Responsive-element-binding-Factor (ERF) supports the horizontal gene transfer responsible for $A P 2$ domain evolved from prokaryotes (Magnani et al., 2004; Wessler, 2005; Wuitschick et al., 2004).

$A P 2$ itself regulate various downstream gene expression since it belongs to a super family of transcription factors (Yant et al., 2010). It suppresses the transcription of SOC1 and
AGAMOUS gene expression and promotes the floral repressor AGL15 and miR156 expression (Adamczyk et al., 2007, Wu et al., 2009). Moreover, AP2 is also involved at the level of translational regulation by miR172 (Aukerman and Sakai 2003). $A P 2$ act pleiotropically and its transcripts have been detected in Arabidopsis in several developmental stages of reproductive as well as in vegetative tissue (Jofuku et al., 1994; Kinoshita et al., 2004; Ripolle et al., 2011; Sharma et al., 2017). Hybridization experiments also showed the presence of $A P 2$ transcripts in various tissues, such as leaf, shoot, stem, root, floral meristem, sepals, petals, and seeds (Wollmann et al., 2010). An eFP Browser, online software was developed to detect the microarray studies and revealed the $A P 2$ distribution from vegetative tissue to reproductive tissue (Winter et al., 2007) (Fig. 3a and b). SHAT1 is an $A P 2$-like gene which expresses in abscission zone during spikelet development in rice. In addition to this, Cleistogamyl $(C l y l)$ is an important gene in barley which expresses itself in spike to promotes cleistogamy (Nair et al., 2010; Wang et al., 2015). Clyl is a member of $A P 2$ gene family, which contains two $A P 2$ domains and miR172 complementary target sequences (Kim et al., 2006). AP2 gene isolated from several crop showing sequence similarity as shown in Figure 4. In Arabidopsis, a single copy is enough for floral development and floral specification; however, it is known in Antirrhinum (Keck et al., 2003);

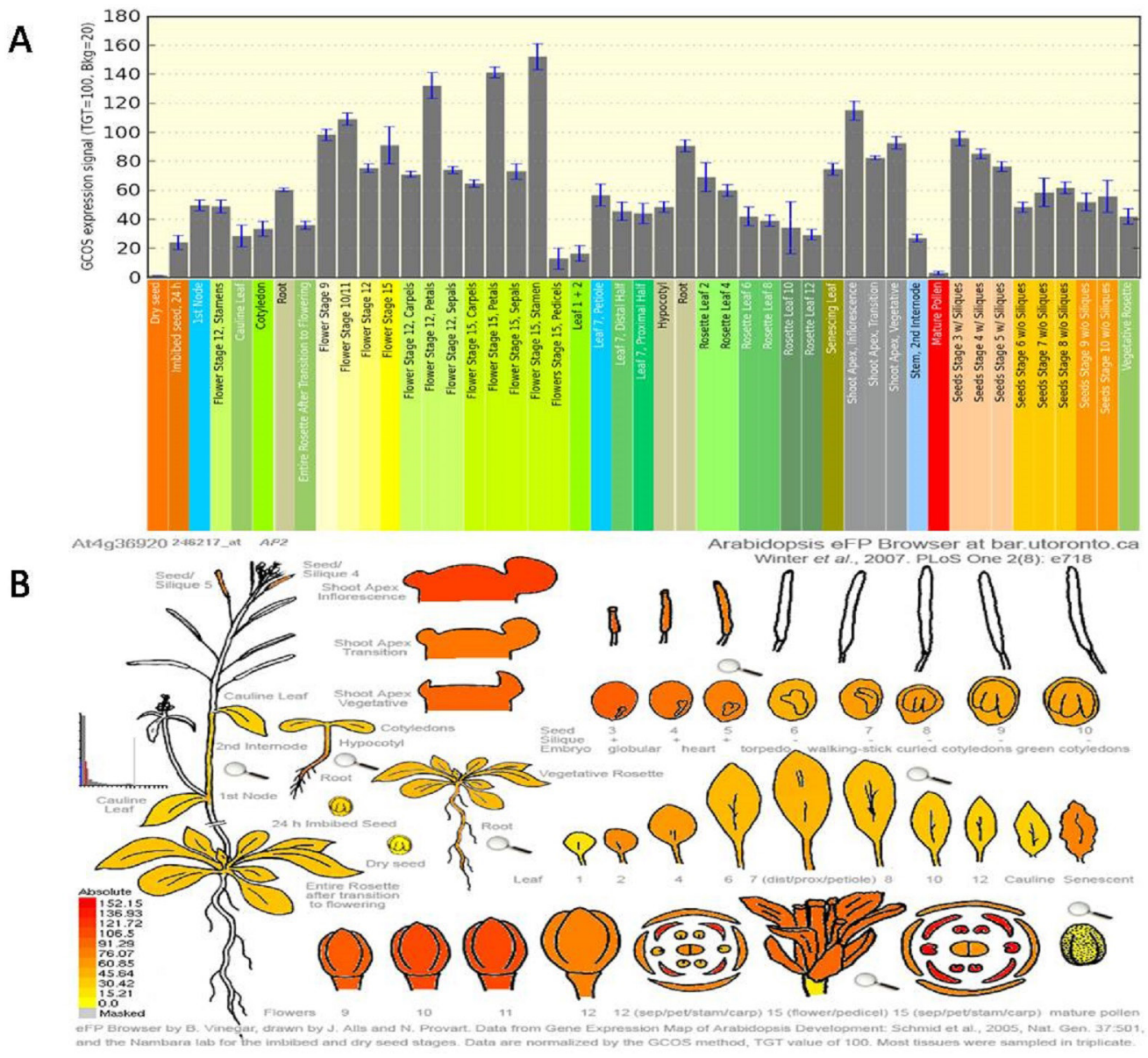

Figure 3. (a) Representation of AP2 expression in vegetative and reproductive tissues in Arabidopsis using eFP Browser online software (b) Representation of level of AP2 expression in different tissue under different stages of Arabidopsis using in silico. 


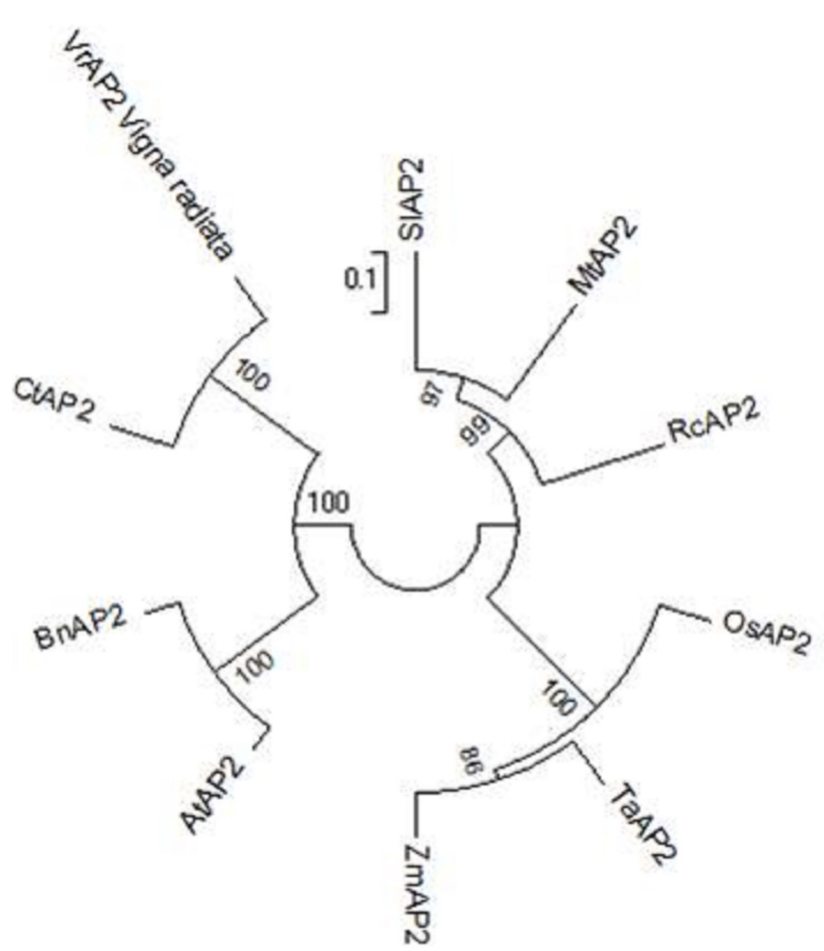

Figure 4. Phylogenetic tree showing relationship of different $A P 2$ gene family members (At-Arabidopsis thaliana Bn-Brassica nigra Zm-Zea mays Ta-Triticum Aestivum Os- Oriza sativum S1- solenum lycopercicum Vr-Vigna radiata Rc Ricinus communis) using MEGA 6.0 .

Petunia hybrida (Maes et al., 2001); Brassica rapa (Liu et al., 2013) showing two AP2-like genes. Brassica juncea which is a tetraploid having three copies of AP2 (Sharma et al., 2018) and tomato (Karlova et al., 2011) having five AP2 copies might be required for flower development.

\section{SIGNIFICANT VALUE OF $A P 2$ GENE IN PLANT SYSTEM}

Several reports are available which reveals that $A P 2$ play significant role in gene regulation (Jofuku et al., 1994; Ripoll et al., 2011). Due to the presence of cis-regulatory elements in both directions it is examined that the $A P 2$ promoter transcribes the genes in both directions hence it is a bidirectional promoter which controls the pleotropic expression in plant developmental biology (Sharma et al., 2017). Moreover, the expression of $A P 2$ is negatively regulated via $m i R 172$, which is nearly $22 \mathrm{bp}$ in length, highly conserved, and non-coding RNA. Due to sequence-complementary, miR172 can easily bind to their targets site on $A P 2$ transcript outside the $A P 2$ domains. Thus, $A P 2$ expression is regulated by $m i R 172$ through one of two or both mechanisms (translation inhibition and transcript cleavage) (Chen, 2004; Zhao et al., 2007). In Arabidopsis, the binding of $m i R 172$ to $A P 2$ transcripts suppresses its expression (Chen, 2004; Zhu and Helliwell, 2011), whereas in barley miR172 digest the AP2 transcripts for negative regulation (Houston et al., 2013). The interaction between miR172 and $A P 2$ transcripts shows that the miR172 regulate $A P 2$ functioning in common bean or Phaseolus vulgaris (Nova-Franco et al., 2015). Some of the genetic modifications within miR172 sequences revealed that AP2-miR172 interaction plays an important role in regulating flowering time in gloxinia plants (Li et al., 2019). Expression of

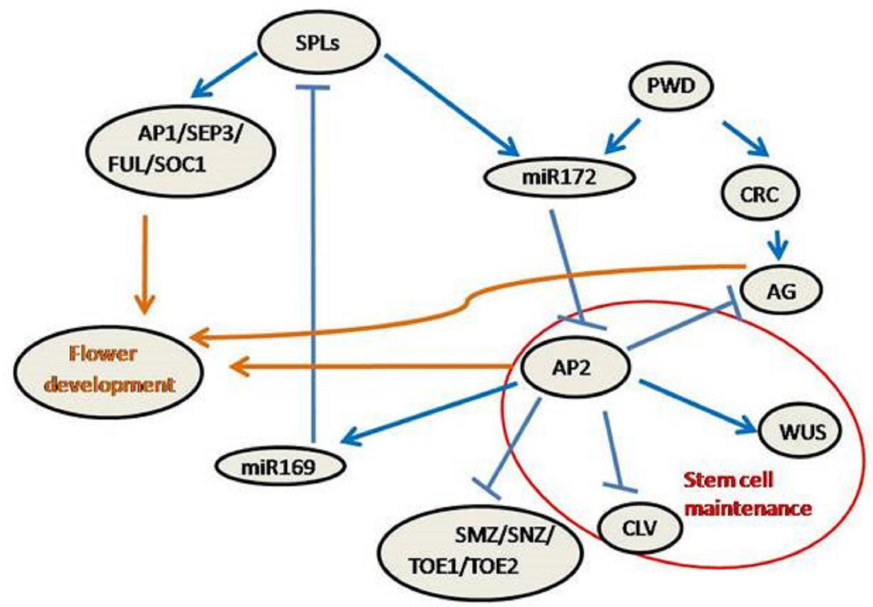

Figure 5. Gene network highlighting the regulatory pathway of $A P 2$ during stem cell maintenance and flower development.

class A gene, such as $A P 2$ transcripts, is reduced in transgenics by over-expression of $m i R 172$, which affects apple fruit weight (Yao et al., 2016). Hence, $A P 2$ shows stochastic interaction between $m i R 172-A P 2$, which is critical for proper floral differentiation and development.

$A P 2$ confers the place and timing of floral organs as well as floral meristem and specification development in plants. It directly promotes the Class C WUSCHEL gene (WUS) gene with down regulating the CLAVATA $(C L V)$ gene to maintain the stem cell niche in floral meristem. However, WUS directly promotes the CLAVATA $(C L V)$ gene and CLAVATA $(C L V)$ represses the activity of $W U S$ for feedback regulation as shown in Figure 5 (Lenhard et al., 2001; Wurschum et al., 2006). It also observed that ap2 mutant lines induced more hexose/sucrose ratios in seeds as compared with wild-type seeds (Ohto et al., 2005). Similarity, loss-of-function of $B n A P 2$ gene showed defects in shape, structure, development, and size of seeds in Brassica nigra (Yan et al., 2012) and RcAP2 gene in Rosa Chinensis regulates the number of rose petals (Han et al., 2018). Different splice variant of HvAP2 revealed the differences in size and shape of barley inflorescence (Houston et al., 2013). Hence, AP2 is an essential gene in length of internode in inflorescence, seed size, and seed mass. However, it could be one of the important genes, which regulate the cascade pathway in floral development in medicinal plant. $A P 2$ transcript in Arabidopsis distorts the developmental changes, such as petals to carpels transition and petals to stamens transition in the outer two whorls of flower structure (Table 1). Furthermore, AP2 regulates replum formation during developing fruit in Arabidopsis (Ripoll et al., 2011). SiAP2, an ortholog of AP2 in tomato involved in ethylene biosynthetic process to confers the fruit ripening (Chung et al., 2010; Rumyana et al., 2011).

Ongoing investigation uncovers that the density of grains in barley inflorescence changes as the interaction between alleles of HvAP2 transcript and miR172 differs (Houston et al., 2013). Thus, the variation in HvAP2 transcripts and miR172 interaction showed that both are involved in the regulation of size and shape of barley inflorescence. Similarly, in Phaseolus vulgaris, legumerhizobia nitrogen-fixing symbiosis system is also influenced by miRNA172-AP2-1 complex (Nova-Franco et al., 2015). 
Table 1. AP2 mutations observed in different whorl of flower in Arabidopsis.

\begin{tabular}{|c|c|c|c|c|c|}
\hline Mutants & Whorl (1) Sepal & Whorl (2) petal & Whorl (3) stamen & Whorl (4) carpel & Reference \\
\hline AP2-1 & Sepal to leaf & $\begin{array}{l}\text { Petal to stamen } \\
\text { Staminoid petal }\end{array}$ & Normal & Normal & Bowman et al.,1989 \\
\hline$A P 2-2$ & Sepal to leaf, carpel and missing & $\begin{array}{l}\text { Petal conver ts to stamen or } \\
\text { stamenoid petal } / \text { missing }\end{array}$ & Stamen reduced in number & $\begin{array}{l}\text { Carpel normal sometimes } \\
\text { unfused }\end{array}$ & Bowman et al.,1991 \\
\hline$A P 2-5$ & Median sepal to carpel & Petal to stamen & Normal & Normal & Kunst et al., 1989 \\
\hline$A P 2-6$ & $\begin{array}{l}\text { Perianth organ to carpel, perianth organ } \\
\text { variably fused }\end{array}$ & $\begin{array}{l}\text { Stamenoid structure fused to } \\
\text { perianth }\end{array}$ & $\begin{array}{l}\text { No. of stamen reduced to } \\
3 \text { or } 4\end{array}$ & Normal & Kunst et al., 1989 \\
\hline$A P 2-7$ & $\begin{array}{l}\text { Perianth reduced to } 2-4 \text { organs, median } \\
\text { sepal to carpel, lateral sepals reduced/ } \\
\text { absent }\end{array}$ & Lack petals & $\begin{array}{l}\text { Stamen fused to perianth, } \\
\text { no. of stamen reduced } \\
\text { to } 1-3\end{array}$ & $\begin{array}{l}\text { Incomplete fusion of } \\
\text { carpels }\end{array}$ & Kunst et al., 1989 \\
\hline$A P 2-8$ & Large sepal & Reduced petal & - & - & Bowman et al., 1991 \\
\hline AP2-9 & Large sepal & Reduced petal/no organ found & Mostly unoccupied & Affected & Bowman et al., 1991 \\
\hline$A P 2-11$ & Sepal to carpeloid like organ & Petal fails to develop & Number of stamen reduced & Reduced in number & Ohto et al., 2005 \\
\hline
\end{tabular}

\section{IMPORTANCE OF $A P 2$ GENE IN CROP IMPROVEMENT}

AP2/ Ethylene-Responsive-element-binding-Factor (ERF) is a super known family, which regulates stress signaling, floral meristem, and floral developmental genes. In rice, over-expression of OsAP37 and OsERF71 genes showed more tolerance against drought, which provides more seed yield (Lee et al., 2016; Oh et al., 2009). OsERF71 is an important gene, which further activates various stress responsive genes, and lignin biosynthesis associated genes causing changes in structure of root. In addition to this, another important $A P 2$ gene (EjAP2-1) characterized from Eriobotrya japonica regulates fruit lignification, which is induced by chilling injury (Zeng et al., 2015). Due to these biotic and abiotic environmental factors, productivity of crop is severely affected. Over the last decade, it was observed that the $A P 2$ candidates play an important role in nitrogen use efficiency (NUE) and plant response toward various abiotic factors. Sixteen AP2 family members were reported as nitrogen deficient responsive genes, which expressed in roots and leaf tissue of rice (Obertello et al., 2015; Yang et al., 2015). Similarly, finding of more nitrogen responsive genes could be beneficial for biological nitrogen fixation in cereal crops using available sequenced databases. NUE depends upon capability of nitrogen uptake by healthy plants under normal condition, which are utilized by the plant for their optimum growth and development (Bi et al., 2009). Due to various factors, the NUE may vary in crop to crop or within the same crop. Furthermore, the stochastic pathways behind nitrogen deficient and nitrogen induced genes may improve the NUE and decreases the unnecessary use of synthetic nitrogen fertilizers for sustainable agriculture.

\section{PHARMACEUTICAL VALUE OF $A P 2$}

$A P 2$ is a well-known gene for its pleotropic expression in vegetative as well as in reproductive tissues in plant system(Sharma et al., 2017). It was found that $A P 2$ contributes stochastically in signaling pathway of various bioactive compounds synthesis, which has huge importance in pharmaceutical industry (Phukan et al., 2017; Udomsom et al., 2016; Xu et al., 2016). Total 171 AP2 members were involved in biosynthesis of bioactive compounds (tanshinone and phenolic acid) characterized from Salvia miltiorrhiza which is used in the treatment of cardiovascular disease in Asia, United States, and several European countries and have more pharmaceutical values. Moreover, the medicine exhibits many other activities such as neuroprotective, anti-inflammatory, antioxidant, and strong antidementia (Ji et al., 2016; Xu et al., 2016). AP2 transcription factors from Ophiorrhiza pumila also regulating camptothecin alkaloid, which is used as an initiator in the synthesis of chemotherapeutic drugs (Udomsom et al., 2016). In Artemisia annua, $A P 2 / E R F$ transcription factor family were also involved in artimisinin and artemisinic acids biosynthesis, which is commonly used in antimalarial drug and further explored for antiviral, anticancerous and antischistosomal drugs (Afrin et al., 2015). In tobacco and Catharanthus roseus, one of the AP2/ $E R F$ family members (GLYCOALKALOID METABOLISM 9) was involved in regulation of toxic alkaloid production which is considered as antinutritional compounds (Cárdenas et al., 2016).

In addition to this, $A P 2$ mutant showed rapid endosperm growth (Zhang et al., 2018), increase in seed size, and seed mass (Ohto et al., 2009), this property of $A P 2$ could be used in medicinal plant using genetic engineering to enhance the valuable product. The novel approach may prove to be beneficial to enhance the inflorescence, seed, and oil production of pharmaceutical important plants.

\section{CONCLUSION}

$A P 2$ plays a pivotal role in gene expression regulation of many plant developmental processes. Recently, miR172-AP2 complex is revealed as an essential regulator in nitrogen-fixing symbiosis and nodulation in legumes. The study could reveal new opportunities in biological nitrogen fixation in cereal crops, which may reduce the gradual use of synthetic nitrogen in agriculture system and improve the NUE. Since the $A P 2$ influences the seed mass as well as seed size, it could directly control seed mass and seed size and may prove to be beneficial for oil plants and cereals for more inflorescence. Moreover, $A P 2$ regulate signaling pathway in biosynthesis of tanshinone and phenolic, which is a traditional Chinese medicine and have high pharmaceutical values. During these stochastic processes, several factors are unclear. It seems highly probable that these regulators should further empirically studied to understand the whole processing.

\section{REFERENCES}

Adamczyk BJ, Lehti-Shiu MD, Fernandez DE. The MADS domain factors AGL15 and AGL18 act redundantly as repressors of the floral transition in Arabidopsis. Plant J, 2007; 50:1007-19. 
Afrin S, Huang JJ, Luo ZY. JA-mediated transcriptional regulation of secondary metabolism in medicinal plants. Sci Bull, 2015; 60(12):1062-72.

Allen MD, Yamasaki K, Ohme-Takagi M, Tateno M, Suzuki M. A novel mode of DNA recognition by a beta-sheet revealed by the solution structure of the GCC-box binding domain in complex with DNA. EMBO J, 1998; 17:5484-96.

Aukerman MJ, Sakai H. Regulation of flowering time and floral organ identity by a microRNA and its APETALA2-like target genes. Plant Cell, 2003; 15:2730-41.

Axtell MJ, Bartel DP. Antiquity of microRNAs and their targets in land plants. Plant Cell, 2005; 17:1658-73.

Bi YM, Kant S, Clarke J, Gidda S, Ming F, Xu J, Rochon A, Shelp BJ, Hao L, Zhao R, Mullen RT, Zhu T, Rothstein SJ. Increased nitrogen-use efficiency in transgenic rice plants over-expressing a nitrogenresponsive early nodulin gene identified from rice expression profiling. Plant Cell Environ, 2009; 32:1749-60.

Bowman JL, Alvarez J, Weigel D, Meyerowitz EM, Smyth DR. Control of flower development in Arabidopsis thaliana by APETALA1 and interacting genes. Development, 1993; 119:721-43.

Bowman JL, Smyth DR, Meyerowitz EM. Genes directing flower development in Arabidopsis. Plant Cell, 1989; 1:37-52.

Bowman JL, Smyth DR, Meyerowitz EM. Genetic interactions among floral homeotic genes of Arabidopsis. Development, 1991; 112:1-20.

Buttner M, Singh KB. Arabidopsis thaliana ethylene-responsive element binding protein (AtEBP), an ethylene-inducible, GCC box DNAbinding protein interacts with an ocs element binding protein. Proc Natl Acad Sci USA, 1997; 94:5961-6.

Cárdenas PD, Sonawane PD, Pollier J, Bossche RV, Dewangan V, Weithorn E, Tal L, Meir S, Rogachev I, Malitsky S, Giri AP. GAME9 regulates the biosynthesis of steroidal alkaloids and upstream isoprenoids in the plant mevalonate pathway. Nate Commun, 2016; 15(7):10654

Chen X. A microRNA as a translational repressor of APETALA2 in Arabidopsis flower development. Science, 2004; 303:2022-5.

Chung MY, Vrebalov J, Alba R, Lee J, McQuinn R, Chung JD, Klein P, Giovannoni J. A tomato (Solanum lycopersicum) APETALA2/ ERF gene, SlAP2a, is a negative regulator of fruit ripening. Plant J, 2010; 64:936-47.

Colombo L, Franken J, Koetje E, van Went J, Dons H, Angenent $\mathrm{G}$, van Tunen A. The petunia MADS box gene FBP11 determines ovule identity. Plant Cell, 1995; 7:1859-68.

Elliott RC, Betzner AS, Huttner E, Oakes MP, Tucker WQ, Gerentes D, Perez P, Smyth DR AINTEGUMENTA, an APETALA2-like gene of Arabidopsis with pleiotropic roles in ovule development and floral organ growth. Plant Cell, 1996; 8:155-68

Finkelstein RR, Wang ML, Lynch TJ, Rao S, Goodman HM. The Arabidopsis abscisic acid response locus ABI4 encodes an APETALA2 domain protein. The Plant Cell, 1998; 10(6):1043-54.

Giraudat J, Hauge BM, Valon C, Smalle J, Parcy F, Goodman HM. Isolation of the Arabidopsis ABI3 gene by positional cloning. Plant Cell, 1992; 4:1251-61.

Han, Y, Tang A, Wan H, Zhang T, Cheng T, Wang J, Yang W, Pan H, Zhang Q. An APETALA2 Homolog, RcAP2, regulates the number of rose petals derived from stamens and response to temperature fluctuations. Front Plant Sci, 2018; 9:481.

Haughn GW, Somerville CR. Genetic control of morphogenesis in Arabidopsis. Dev Genet, 1998; 9:73-89.

Houston K, McKim SM, Comadran J, Bonar N, Druka I, Uzrek N, Cirillo E, Guzy-Wrobelska J, Collins NC, Halpin C, Hansson M, Dockter C, Druka A, Waugh R. Variation in the interaction between alleles of HvAPETALA2 and microRNA172 determines the density of grains on the barley inflorescence. Proc Natl Acad Sci USA, 2013; 110:16675-80.

Huala E, Sussex IM. LEAFY interacts with floral homeotic genes to regulate Arabidopsis floral development. Plant Cell, 1992; 4:901-13.

Irish VF, Sussex IM. Function of the apetala-1 gene during Arabidopsis floral development. Plant Cell, 1990; 2:741-53.

Ji AJ, Luo HM, Xu ZC, Zhang X, Zhu YJ, Liao BS, Yao H, Song JY, Chen SL. Genome-wide identification of the AP2/ERF gene family involved in active constituent biosynthesis in Salvia miltiorrhiza. The Plant Genome, 2016; 9(2)

Jofuku KD, den Boer BG, Van Montagu M, Okamuro JK. Control of Arabidopsis flower and seed development by the homeotic gene APETALA2. Plant Cell, 1994; 6:1211-25.

Kagaya Y, Ohmiya K, Hattori T. RAV1, a novel DNA-binding protein, binds to bipartite recognition sequence through two distinct DNAbinding domains uniquely found in higher plants. Nucleic Acids Res, 1999; 27(2):470-8.

Karlova R, Rosin FM, Busscher-Lange J, Parapunova V, Do PT, Fernie AR, Fraser PD, Baxter C, Angenent GC, de Maagd RA. Transcriptome and metabolite profiling show that APETALA2a is a major regulator of tomato fruit ripening. Plant Cell, 2011; 23:923-41.

Keck E, McSteen P, Carpenter R, Coen E. Separation of genetic functions controlling organ identity in flowers. The EMBO Journal, 2003; 22(5):1058-66.

Kim S, Soltis PS, Wall K, Soltis DE. Phylogeny and domain evolution in the APETALA2-like gene family. Mol Biol Evol, 2006; 23:107-20.

Kinoshita T, Miura A, Choi Y, Kinoshita Y, Cao X, Jacobsen SE, Fischer RL, Kakutani T. One-way control of FWA imprinting in Arabidopsis endosperm by DNA methylation. Science, 2004; 303:521-3.

Klucher KM, Chow H, Reiser L, Fischer RL. The AINTEGUMENTA gene of Arabidopsis required for ovule and female gametophyte development is related to the floral homeotic gene APETALA2. Plant Cell, 1996; 8:137-53.

Komaki MK, Kitotaka O, Nishino E, Shimura Y. Isolation and characterization of novel mutants of Arabidopsis thaliana defective in flower development. Development, 1988; 104:195-203.

Krizek BA, Fletcher JC. Molecular mechanisms of flower development: an armchair guide. Nat Rev Genet, 2005; 6:688-98

Kunst L, Klenz JE, Martinez-Zapater J, Haughn GW. AP2 gene determines the identity of perianth organs in flowers of Arabidopsis thaliana. Plant Cell, 1989; 1:1195-208.

Lauter N, Kampani A, Carlson S, Goebel M, Moose SP microRNA172 down-regulates glossy15 to promote vegetative phase change in maize. Proc Natl Acad Sci USA, 2005; 102:9412-7.

Lee DK, Jung H, Jang G, Jeong JS, Kim YS, Ha SH, Do Choi Y, Kim JK. Overexpression of the OsERF71 transcription factor alters rice root structure and drought resistance. Plant Physiol, 2016; 172:575-88.

Lenhard M, Bohnert A, Jurgens G, Laux T. Termination of stem cell maintenance in Arabidopsis floral meristems by interactions between WUSCHEL and AGAMOUS. Cell, 2001; 105:805-14.

Li XY, Guo F, Ma SY, Zhu MY, Pan WH, Bian HW. Regulation of flowering time via microRNA172-mediated APETALA2-like expression in ornamental gloxinia (Sinningia speciosa). J Zhejiang Univ Sci B, 2019; 20(4):322-31.

Licausi F, Giorgi FM, Zenoni S, Osti F, Pezzotti M, Perata P. Genomic and transcriptomic analysis of the AP2/ERF superfamily in Vitis vinifera. BMC Genomics, 2010; 11:719.

Liu Y, Wei W, Ma K, Li J, Liang Y, Darmency H. Consequences of gene flow between oilseed rape (Brassica napus) and its relatives. Plant Sci, 2013; 211:42-51.

Maes T, Van de Steene N, Zethof J, Karimi M, D’Hauw M, Mares G, Van Montagu M, Gerats T. Petunia Ap2-like genes and their role in flower and seed development. The Plant Cell, 2001; 13(2):229-44.

Magnani E, Sjolander K, Hake S. From endonucleases to transcription factors: evolution of the AP2 DNA binding domain in plants. Plant Cell, 2004; 16:2265-77.

Moose SP, Sisco PH. Glossy15, an APETALA2-like gene from maize that regulates leaf epidermal cell identity. Genes Dev, 1996; 10:3018-27.

Nair SK, Wang N, TuruspekovY, Pourkheirandish M, Sinsuwongwa S, Chen G, Sameri M, Tagiri A, Honda I, Watanabe Y, Kanamoric H, Wickerd T, Steine N, Nagamuraa Y, Matsumotoa T, Komatsudaet T. Cleistogamous flowering in barley arises from the suppression of microRNAguided HvAP2 mRNA cleavage. Proc Natl Acad Sci USA, 2010; 107:490-5. 
Nakano T, Suzuki K, Fujimura T, Shinshi H. Genome-wide analysis of the ERF gene family in Arabidopsis and rice. Plant Physiol, 2006; 140:411-32.

Nova-Franco B, Iniguez LP, Valdes-Lopez O, AlvaradoAffantranger X, Leija A, Fuentes SI, Ramirez M, Paul S, Reyes JL, Girard L, Hernandez G. The micro-RNA72c APETALA2-1 node as a key regulator of the common bean-Rhizobium etli nitrogen fixation symbiosis. Plant Physiol, 2015; 168:273-91.

Obertello M, Shrivastava S, Katari MS, Coruzzi GM. Crossspecies network analysis uncovers conserved nitrogen-regulated network modules in Rice. Plant Physiol, 2015; 168(4):1830-43.

Oh SJ, Kim YS, Kwon CW, Park HK, Jeong JS, Kim JK. Overexpression of transcription factor AP37 in rice improves grain yield under drought conditions. Plant Physiol, 2009; 150:1368-79.

Ohme-Takagi M, Shinshi H. Ethylene-inducible DNA binding proteins that interact with an ethylene-responsive element. Plant Cell, 1995; $7: 173-82$.

Ohto MA, Fischer RL, Goldberg RB, Nakamura K, Harada JJ. Control of seed mass by APETALA2. Proc Natl Acad Sci USA, 2005; 102:3123-28.

Ohto MA, Floyd SK, Fischer RL, Goldberg RB, Harada JJ. Effects of APETALA2 on embryo, endosperm, and seed coat development determine seed size in Arabidopsis. Sex Plant Reprod, 2009; 22(4):277-89.

Okamuro JK, Caster B, Villarroel R, Van Montagu M, Jofuku KD.

The AP2 domain of APETALA2 defines a large new family of DNA binding proteins in Arabidopsis. Proc Natl Acad Sci USA, 1997; 94:7076-81.

Pelaz S, Ditta GS, Baumann E, Wisman E, Yanofsky MF. B and $\mathrm{C}$ floral organ identity functions require SEPALLATA MADS-box genes. Nature, 2000; 405:200-3.

Phukan UJ, Jeena GS, Tripathi V, Shukla RK. Regulation of Apetala2/Ethylene response factors in plants. Front Plant Sci. 2017; 21(8):150.

Riechmann JL, Meyerowitz EM. The AP2/EREBP family of plant transcription factors. Biol Chem, 1998; 379:633-46.

Ripoll JJ, Roeder AH, Ditta GS, Yanofsky MF. A novel role for the floral homeotic gene APETALA2 during Arabidopsis fruit development. Development, 2011; 138:5167-76.

Sahu R, Sharaff M, Pradhan M, Sethi A, Bandyopadhyay T, Mishra VK, Chand R, Chowdhury AK, Joshi AK, Pandey SP. Elucidation of defense-related signaling responses to spot blotch infection in bread wheat (Triticum aestivum L.). Plant J, 2016; 86:35-49.

Schultz EA, Haughn GW. Genetic analysis of the floral initiation process (FLIP) in Arabidopsis. Development, 1993; 119:745-65.

Shannon S, Meeks-Wagner DR. Genetic interactions that regulate inflorescence development in Arabidopsis. Plant Cell, 1993; 5:639-55.

Sharma P, Kumar V, Singh SK, Thakur S, Siwach P, Sreenivasulu Y, Srinivasan R, Bhat SR. Promoter trapping and deletion analysis show arabidopsis thaliana apetala2 gene promoter is bidirectional and functions as a pollen and ovule-specific promoter in the reverse orientation. Appl Biochem Biotechnol, 2017; doi:10.1007/s12010-017-2420-9

Sharma P, Watts A, Kumar V, Srinivasan R, Siwach P. Cloning, characterization and expression analysis of APETALA2 genes of Brassica juncea (L.) Czern. Indian J Exp Biol, 2018; 56:604-10.

Udomsom N, Rai A, Suzuki H, Okuyama J, Imai R, Mori T, Nakabayashi R, Saito K, Yamazaki M. Function of AP2/ERF transcription factors involved in the regulation of specialized metabolism in Ophiorrhiza pumila revealed by transcriptomics and metabolomics. Frontiers Plant Sci, 2016; 7:1861

Wang N, Ning SZ, Wu JZ, Tagiri A, Komatsuda T. An epiallele at cly1 affects the expression of floret closing (Cleistogamy) in barley. Genetics, 2015; 199:95-104; doi:10.1534/genetics.114.171652

Wessler SR. Homing into the origin of the AP2 DNA binding domain. Trends Plant Sci, 2005; 10(2):54-6.

Wilson K, Long D, Swinburne J, Coupland G. A Dissociation insertion causes a semidominant mutation that increases expression of TINY, an Arabidopsis gene related to APETALA2. Plant Cell, 1996; 8: $659-71$.
Winter D, Vinegar B, Nahal H, Ammar R, Wilson GV, Provart NJ. An electronic fluorescent pictograph browser for exploring and analyzing large-scale biological data sets. PLoS One, 2007; 2:e718.

Wollmann H, Mica E, Todesco M, Long JA, Weigel D. On reconciling the interactions between APETALA2, miR172 and AGAMOUS with the ABC model of flower development. Development, 2010; 137:3633-42.

Wu G, Park MY, Conway SR, Wang JW, Weigel D, Poethig RS The sequential action of miR156 and miR172 regulates developmental timing in Arabidopsis. Cell, 2009; 138(4):750-9.

Wuitschick JD, Lindstrom PR, Meyer AE, Karrer KM. Homing endonucleases encoded by germ line-limited genes in Tetrahymena thermophile have APETELA2 DNA binding domains. Eukaryotic Cell, 2004; 685-694; doi:10.1128/EC.3.3.685-694.2004

Wurschum T, Gross-Hardt R, Laux T. APETALA2 regulates the stem cell niche in the Arabidopsis shoot meristem. Plant Cell, 2006; 18:295-307.

Xu H, Song J, Luo H, ZhangY, Li Q, ZhuY, Xu J, Li Y, Song C, Wang B, Sun W, Shen G, Zhang X, Qian J, Ji A, Xu Z, Luo X, He L, Li C, Sun C, Yan H, Cui G, Li X, Li X, Wei J, Liu J, Wang Y, Hayward A, Nelson D, Ning Z, Peters RJ, Qi X, Chen S. Analysis of the genome sequence of the medicinal plant Salvia miltiorrhiza. Mol Plant, 2016; 9:949-952; doi:10.1016/j.molp.2016.03.010

Yan X, Zhang L, Chen B, Xiong Z, Chen C, Wang L, Yu J, Lu $\mathrm{C}$, Wei W. Functional identification and characterization of the Brassica napus transcription factor gene BnAP2, the ortholog of Arabidopsis thaliana APETALA2. PLoS One, 2012; 7:e33890; doi:10.1371/journal. pone. 0033890

Yang W, Yoon J, Choi H, Fan Y, Chen R, An G. Transcriptome analysis of nitrogen-starvation-responsive genes in rice. BMC Plant Biol, $2015 ; 15: 31$.

Yant L, Mathieu J, Dinh TT, Ott F, Lanz C, Wollmann H, Chen $\mathrm{X}, \mathrm{Schmid}$ M. Orchestration of the floral transition and floral development in Arabidopsis by the bifunctional transcription factor APETALA2. Plant Cell, 2010; 22:2156-70.

Yao JL, Tomes S, Xu J, Gleave AP. How microRNA172 affects fruit growth in different species is dependent on fruit type. Plant Signal Behav, 2016; 11:e1156833.

Zeng JK, Li X, Xu Q, Chen JY, Yin XR, Ferguson IB, Chen $\mathrm{KS}$. EjAP2-1, an AP2/ERF gene, is a novel regulator of fruit lignification induced by chilling injury, via interaction with EjMYB transcription factors. Plant Biotechnol J, 2015; 13:1325-34.

Zhang G, Chen M, Chen X, Xu Z, Guan S, Li LC, Li A, Guo J, Mao L, Ma Y. Phylogeny, gene structures, and expression patterns of the ERF gene family in soybean (Glycine max L.). J Exp Bot, 2008; 59: 4095-107.

Zhao L, Kim Y, Dinh TT, Chen X. miR172 regulates stem cell fate and defines the inner boundary of APETALA3 and PISTILLATA expression domain in Arabidopsis floral meristems. Plant J, 2007; 51:840-9.

Zhu QH, Helliwell CA. Regulation of flowering time and floral patterning by miR172. J Exp Bot, 2011; 62:487-95.

Zhuang J, Cai B, Peng RH, Zhu B, Jin XF, Xue Y, Gao F, Fu XY, Tian YS, Zhao W, Qiao YS, Zhang Z, Xiong AS, Yao QH. Genomewide analysis of the AP2/ERF gene family in Populus trichocarpa. Biochem Biophys Res Commun, 2008; 371:468-74.

How to cite this article:

Sharma P, Singh R, Sehrawat N. A critical review on: Significance of floral homeotic APETALA2 gene in plant system. J Appl Pharm Sci, 2020; 10(1):124-130. 